\title{
PPPL-3019
}

UC-420,423,424,425

\section{TFTR RADIATION CONTOUR AND SHIELDING EFFICIENCY MEASUREMENTS DURING D-D OPERATIONS}

\author{
BY
}

H.W. KUGEL, G. ASCIONE, S. ELWOOD, ET AL.

NOVEMBER 1994

\section{MASTER}

DISTRIBUTION OF THIS DOCUMENT IS UNLIMITED

PRINCETON

pLASMA PHYSICS

LABORATORY

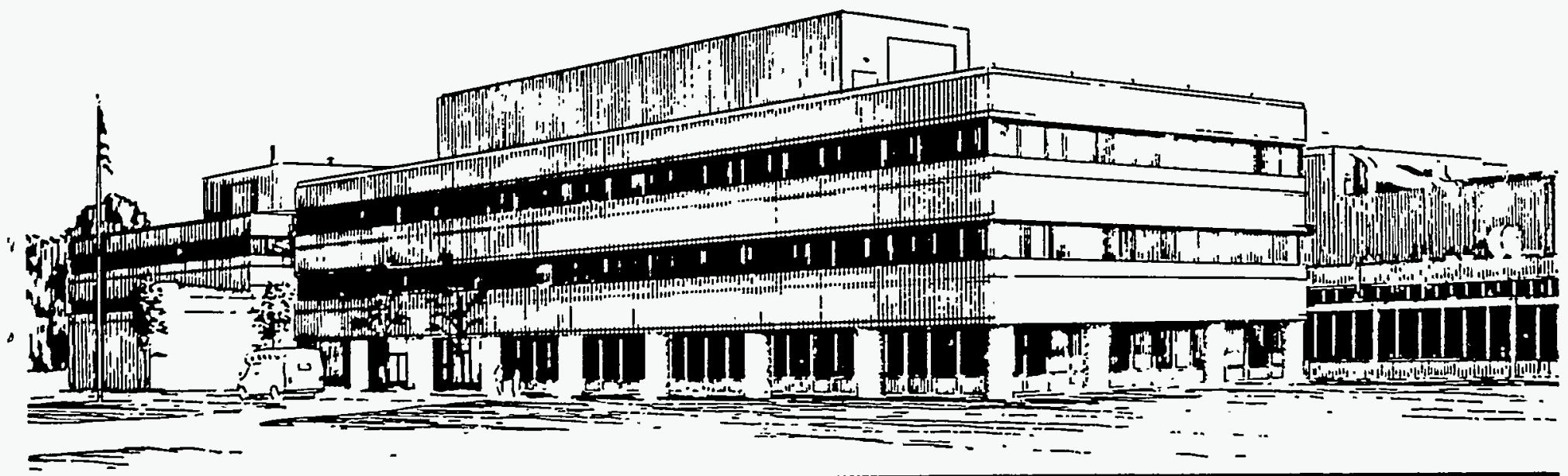

\section{PRINCETON UNIVERSITY, PRINCETON, NEW JERSEY}




\section{NOTICE}

This report was prepared as an account of work sponsored by an agency of the United States Government. Neither the United States Government nor any agency thereof, nor any of their employees, makes any warranty, express or implied, or assumes any legal liability or responsibility for the accuracy, completeness, or usefulness of any information, apparatus, product, or process disclosed, or represents that its use would not infringe privately owned rights. Reference herein to any specific commercial produce, process, or service by trade name,-trademark, manufacturer, or otherwise, does not necessarily constitute or imply its endorsement, recommendation, or favoring by the United States Government or any agency thereof. The views and opinions of authors expressed herein do not necessarily state or reflect those of the United States Government or any agency thereof.

\section{NOTICE}

This report has been reproduced from the best available copy. Available in paper copy and microfiche.

Number of pages in this report: 10

DOE and DOE contractors can obtain copies of this report from:

Office of Scientific and Technical Information

P.O. Box 62

Oak Ridge, TN 37831;

(615) $576-8401$.

This report is publicly available from the:

National Technical Information Service

Department of Commerce

5285 Port Royal Road

Springfield, Virginia 22161

(703) $487-4650$ 


\section{DISCLAIMER}

Portions of this document may be illegible in electronic image products. Images are produced from the best available original document. 


\section{TFTR RADIATION CONTOUR AND SHIELDING EFFICIENCY MEASUREMENTS DURING D-D OPERATIONS}

H. W. Kugel, G. Ascione, S. Elwood, J. Gilbert, D. Hwang, M. Lewis, J. Levine, L.-P. Ku, and K. Rule Princeton Plasma Physics Laboratory Princeton University, P. O. Box 451 Princeton, NJ 08543

\section{ABSTRACT}

Extensive neutron and gamma radiation contour, shielding efficiency, and spectral measurements were performed during high power TFTR D-D operations at the tokamak Test Cell inner walls, ceiling, roof, and outer walls, in nearby control rooms, work areas, and personnel pathways, outdoors along the site fence at $125 \mathrm{~m}$, and out to the nearest property lines at $180 \mathrm{~m}$. The results confirmed that the efficiency of the basic radiation shielding was sufficient to allow the TFTR D-T experimental plan, and provide empirical guidance for simulating the radiation fields of future fusion reactors.

\section{INTRODUCTION}

The initial startup phase of large fusion reactors requires a test sequence beginning with hydrogen plasmas, followed by testing with low power deuterium (D-D) plasmas, before proceeding to high power deuteriumtritium (D-T) plasmas. Given the complex geometric and material density configurations involved, a thorough experimentally based understanding of $D-D$ radiation field characteristics is important for qualifying a reactor's radiation shielding before starting high power operations with tritium fuel. This approach was followed as the Tokamak Fusion Test Reactor (TFTR) prepared for introduction of tritium fuel and beginning high power D-T operations. ${ }^{1}$ Preliminary measurements were discussed previously. ${ }^{2}$ This paper presents extensive new results of radiation spectral, contour, and shielding efficiency measurements, during high power D-D operations with record neutron yields prior to the introduction of tritium fuel.

\section{EXPERIMENTAL GEOMETRY}

The TFTR design objective in areas immediately outside the Test Cell walls is to limit the total radiation dose-equivalent due to all sources to less than $10^{-2} \mathrm{~Sv}$ per calendar year. Figs. 1 and 2, respectively, show schematic
F. Hajnal, N. Azziz, P. Goldhagen,

G. Klemic, and P. Shebell

U. S. Department of Energy

Environmental Measurements Laboratory

376 Hudson Street

New York, NY 10014-3621

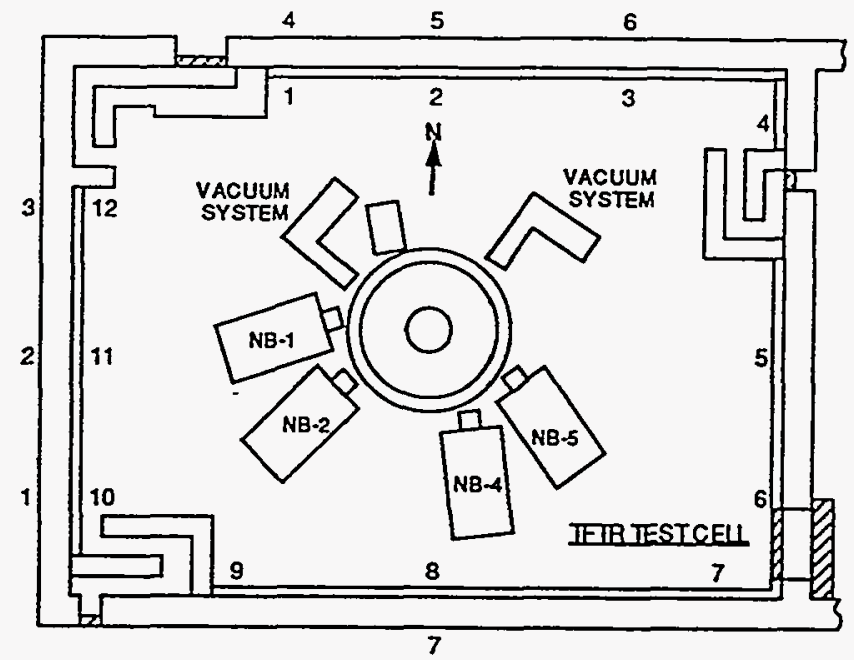

Fig. 1. Schematic plan view of TFTR Test Cell. The numbers at the inside and outside of the shield wall give measurement locations discussed in the text.

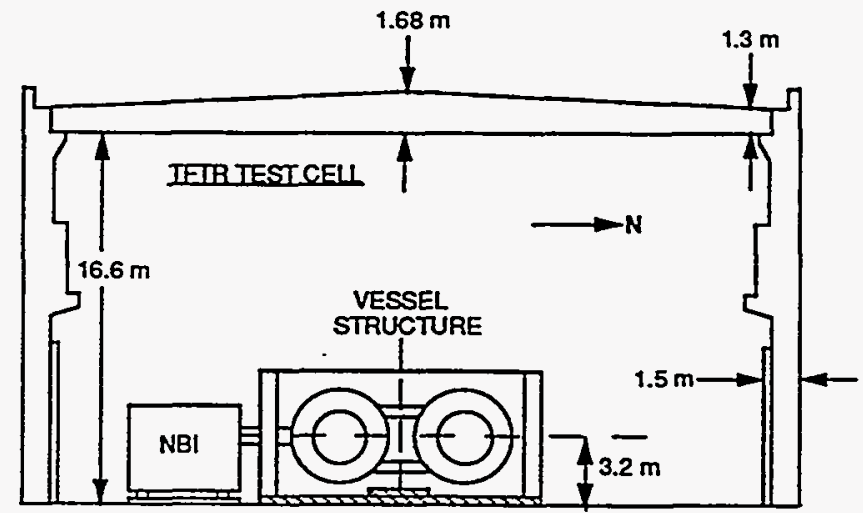

Fig. 2. Schematic elevation view of TFIR Test Cell showing the concrete wall and roof shielding. 
plan and elevation views of the TFTR Test Cell. In Fig. 1, the numbers along the walls indicate the locations of measurements discussed below. The interior Test Cell dimensions are nominally $46 \mathrm{~m}$ by $35 \mathrm{~m}$ by $16.6 \mathrm{~m}$ high with a total volume of about $2.7 \times 10^{4} \mathrm{~m}^{3}$. The total volume occupied by the TFTR vessel structures and other Test Cell hardware changes as the experimental configuration changes, but is estimated to be in the range of about $5-8 \%$ of the total Test Cell volume. The TFTR vessel is positioned above a $1.8 \mathrm{~m}$ thick platform with a stainless steel (304-SS) framing filled with borated concrete. The borated concrete has a density of $2.24 \mathrm{~g} / \mathrm{cm}^{3}$ and is a limestone aggregate with a boron content of $0.8 \%$ of the total concrete weight and is reinforced with stainless steel rebars. Penetrations in the floor to the Test Cell Basement allow access to the vessel for the coil leads, diagnostic equipment, and mechanical piping. Beyond the vessel platform, the floor is a $0.91 \mathrm{~m}$ thick concrete slab, of which $0.3 \mathrm{~m}$ is a borated limestone aggregate type concrete. The roof, which varies in thickness from $1.68 \mathrm{~m}$ above the vessel to $1.2 \mathrm{~m}$ at the edges, and the walls of thickness $1.2 \mathrm{~m}$, are of ordinary concrete reinforced with steel rebars (Fig. 2). An additional $0.3 \mathrm{~m}$ of concrete shielding consisting of $1.5 \mathrm{~m}$ wide concrete panels, has been bolted to the walls up to an elevation of $7.3 \mathrm{~m}$ above the floor. The nearby Hot Cell area provides an additional $1.2 \mathrm{~m}$ of concrete shielding in the eastward direction. The shield walls are ordinary unborated concrete. The aggregates used in the shielding concrete are limestone or quartz with minimal weight percentages of sodium, aluminum, and. magnesium oxide.

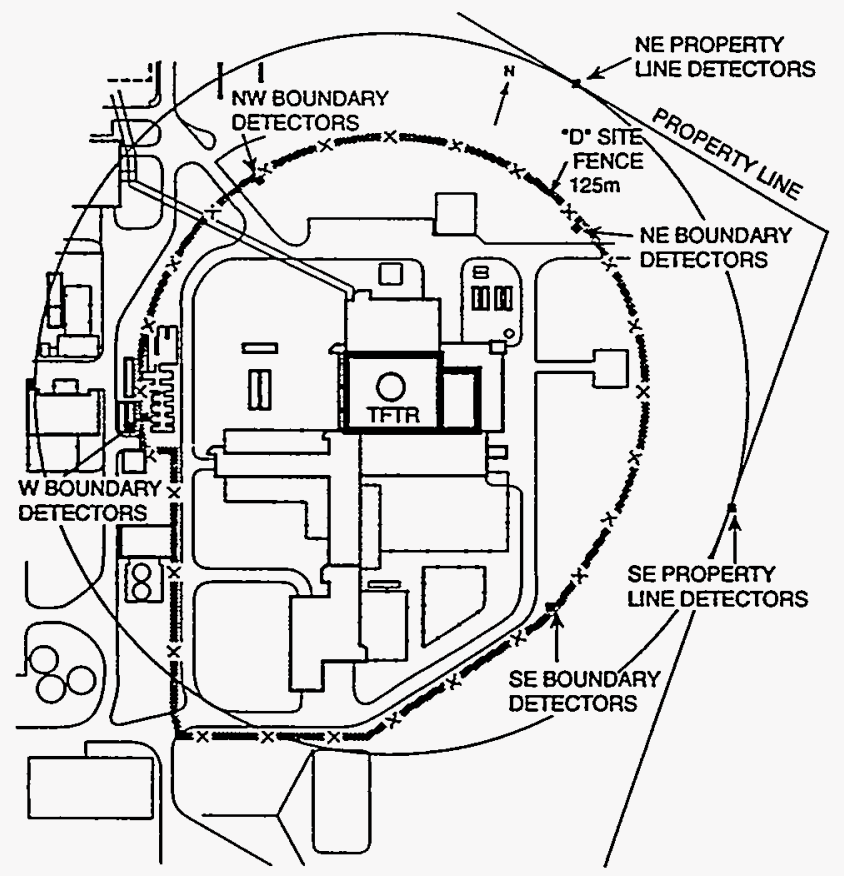

Fig. 3. Schematic plan view of TFTR site, showing the four radiation Remote Measuring System trailers at the TFTR (D-site) fence $(R=125 \mathrm{~m})$, and nearest PPPL property lines $(R=180 \mathrm{~m})$.
The TFTR shielding design objective for the PPPL property lines is to limit the total prompt and delayed doseequivalent from all sources and pathways to $10^{-4} \mathrm{~Sv}$ per calendar year. Fig. 3 shows a schematic plan view of the TFTR site, buildings, the radiation Remote Measuring System at the site fence at major radius $R=125 \mathrm{~m}$, and nearest PPPL property lines in the northeast and southeast directions at major radius $R=180 \mathrm{~m}$.

\section{MEASUREMENT PROCEDURE}

TFTR is operated with plasma pulse lengths of 5 to $10 \mathrm{sec}$ with dwell times between pulses of about 8 to 15 minutes. Intense D-D neutron yields occur for 1 to $2 \mathrm{sec}$ during the plasma current pulse when 70 to $120 \mathrm{keV}$ neutral beams are injected at powers up to $33 \mathrm{MW}$. The neutron yields can vary with machine conditions and the selected plasma parameters. TFTR fusion neutron yields are measured at the vessel by an array of extensively calibrated neutron detectors to within experimental uncertainties of about \pm 13 to $15 \%$. In order to maximize the signal-tobackground ratio for all electronic detector measurements reported in this work, the dose-equivalent measurements at remote locations were measured per TFTR neutron pulse as distinguished from integral measurements integrated over many pulses. The stationary measurements, at fixed reference fiducial locations, and the portable measurements, were synchronized to the TFTR system clock. Due to the efficiency of the shielding, measurements of TFTR gamma and neutron dose-equivalents could not be performed during low power D-D operations. The outdoor measurements required plasmas yielding at least $1 \times 10^{16} \mathrm{D}$-D neutrons per pulse.

In this work, the dose-equivalent responding neutron detectors were mostly ${ }^{3} \mathrm{He}$ proportional counters in $25 \mathrm{~cm}$ diameter polyethylene moderating spheres. The lower limit. of detection (LLD) was $6 \times 10^{-11} \mathrm{~Sv} /$ count. The gamma/X detectors were pressurized argon ionization chambers configured for standard environmental monitoring requirements. The LLD for detectors near the Test Cell walls was $2 \times 10^{-9} \mathrm{~Sv} /$ count. The LLD for detectors in the far field region was $10^{-11} \mathrm{~Sv} /$ count. Similar portable detectors were used for the measurements at remote locations. The neutron dose-equivalent detectors had an LLD of $4.6 \times 10^{-11} \mathrm{~Sv} /$ count. The gamma dose-equivalent detectors had a LLD of $10^{-11} \mathrm{~Sv} /$ count.

In addition to these primary detectors used for the radiation contour and shielding efficiency measurements, many other PPPL detection systems were used for comoborative and associated systematic studies, as well as, continuous radiation monitoring in control rooms, work areas, and personnel pathways near the tokamak Test Cell. In addition, the U. S. DOE Environmental Measurements Laboratory (EML) performed special neutron spectral measurements using activation foils in the tokamak Test Cell and a 12 Bonner sphere array of $\mathrm{BF}_{3}$ detectors outside the Test Cell. 
All of the detector systems were calibrated using rigorous and extensive calibration procedures. These included on-site National Institute of Standards and Technology (NIST) traceable standards, and off-site NIST traceable standards at vendors, and other laboratories.

\section{MEASUREMENT RESULTS}

The results are presented below in a sequence that begins with the measurement locations closest to the vessel in the TFIR Test Cell, proceeds to the outside walls of the Test Cell, and then outward toward the nearest property line at $180 \mathrm{~m}$ from the center of TFTR.

\section{A. INSIDE TFTR TEST CELL}

Fig. 4 shows the results of measurements along the Test Cell ceiling ( $16.6 \mathrm{~m}$ above the floor) proceeding above the TFTR vessel from south to north. The higher: energy neutron distribution (E1n) is strongly peaked over the vessel, whereas the lower energy neutron distribution (R1n), which includes scattered thermal energy neutrons, exhibits a more uniform distribution, as do the gammas (R1g). This behavior is consistent with the results of simulations which found the gamma distributions to be relatively constant and the low energy neutron distributions be less peaked than the high energy neutron distributions due to the effects of multiple scattering. 3,4

Fig. 5 shows neutron and gamma dose-equivalent per TFTR D-D neutron profile measurements made along a vertical line on the inside of the Test Cell north wall to a height of about $15 \mathrm{~m}$. The lower energy neutron (R1n) and the gamma (RIg) dose-equivalent distributions were

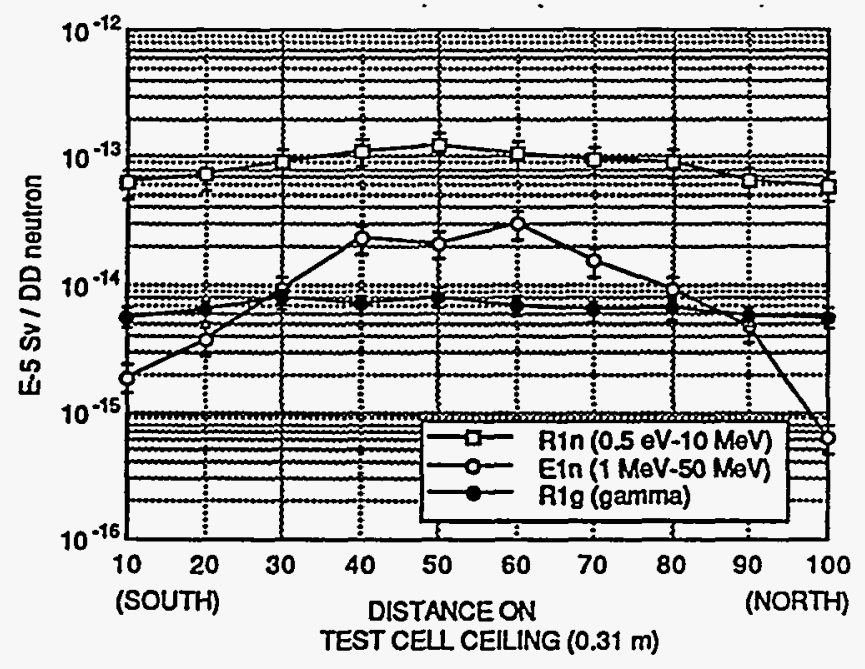

Fig. 4. Measured neutron and gamma dose-equivalents per D-D neutron along the Test Cell ceiling proceeding from south to north (see Fig. 1). The detectors were vendor dosimeters as follows; neutron type R1n (CR-39 and TLD; $0.5 \mathrm{eV}-10 \mathrm{MeV}$ ), neutron type E1n (Lexan; $1 \mathrm{MeV}-50$ $\mathrm{MeV}$ ), gamma type Rlg (film badge).

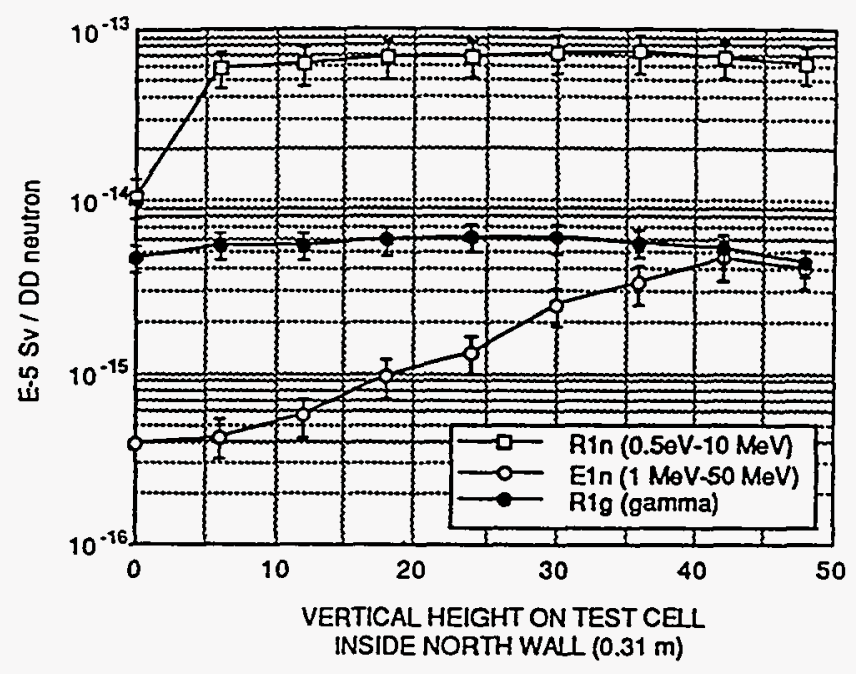

Fig. 5. Measured neutron and gamma dose-equivalents per TFIR D-D neutron along a vertical line on the inside of the Test Cell north wall to a height of about $15 \mathrm{~m}$. The detectors were vendor dosimeters as follows; neutron type Rin (CR-39 and TLD; $0.5 \mathrm{eV}-10 \mathrm{MeV}$ ), neutron type Ein (Lexan; $1 \mathrm{MeV}$ - $50 \mathrm{MeV}$ ), gamma type R1g (film badge).

relatively uniform, whereas the high energy neutron distribution (E1n) increased with height above the floor hardware and lower vessel superstructure, and then started to. decrease as the line-of-sight passed through the massive upper vessel structures (Fig. 2). Measurements outside the Test Cell indicated similar neutron and gamma doseequivalent behavior and are discussed below.

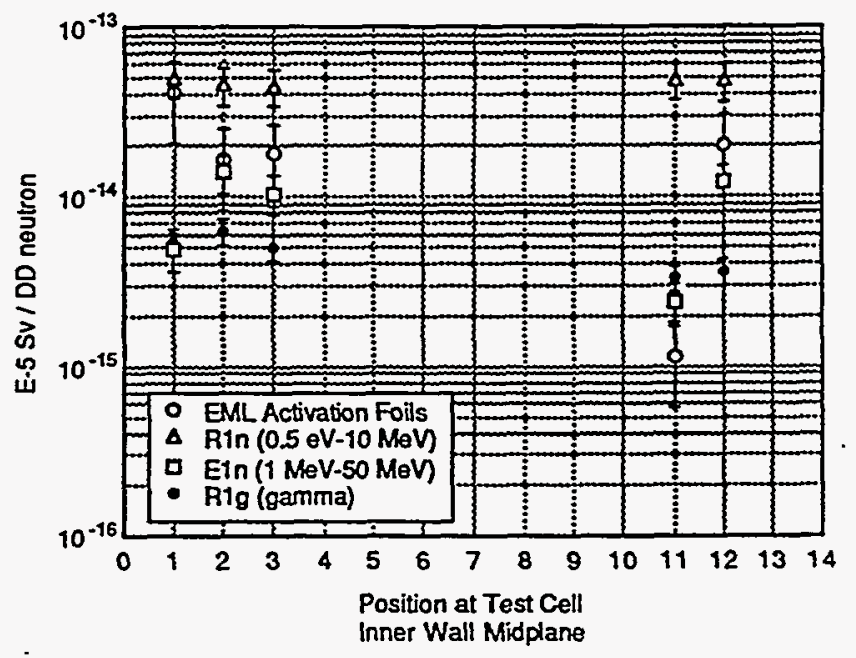

Fig. 6. Measured neutron and gamma dose-equivalents per TFTR D-D neutron along the midplane of the Test Cell inner wall. The measurement locations are indicated in Fig. 1. The detectors were the ELM neutron activation foils 5 , and vendor dosimeters as follows; neutron type R1n (CR39 and TLD; $0.5 \mathrm{eV}-10 \mathrm{MeV}$ ), neutron type EIn (Lexan; $1 \mathrm{MeV}$ - $50 \mathrm{MeV}$ ), gamma type R1g (film). 
Fig. 6 summarizes neutron dose-equivalent per TFTR $D-D$ neutron measurements on the inner Test Cell wall midplane of the tokamak Test Cell. The measurement locations are indicated in Fig. 1. Shown are the average of the neutron measurements made using commercial etch track detectors with high and low energy neutron thresholds and film badges. Included in Fig. 6 for comparison are the results of the EML activation foil measurements. 5 Although the measurements shown in Fig. 6 have different spectral sensitivities, they are in general agreement and exhibit variations with Test Cell position due to the complex material density distribution. These variations with Test Cell position were also indicated in the previous measurements. ${ }^{2}$ Fig. 6 also includes the results of gamma dose-equivalent measurements at the same locations. In the Test Cell, the neutron-to-gamma dose-equivalent ratios for $D-D$ discharges were in a range from about 10 to 14 . Similar ratios were also observed at various Test Cell Basement locations and are attributed to neutron streaming through the experimental and diagnostic equipment penetrations. Outside the Test Cell, away from penetrations in the shielding, the measured neutron dose-equivalents were less than the gamma dose-equivalents.

\section{B. AT TFTR TEST CELL OUTER WALL}

Fig. 7 shows the results of measurements neutron and gamma dose-equivalent per TFTR D-D neutron along the horizontal midplane at the outside of the Test Cell walls. The measurement locations are indicated in Fig. 1. The relatively low neutron dose-equivalents were measured at Positions 1 and 2 which are shielded by neutral beam injection systems. Higher dose-equivalents were measured at Positions 5 and 6, which are in northward directions having minimal shielding by the vessel vacuum pump duct and Test Cell equipment. The dose-equivalents at Positions 5 and 6 may also contain contributions from nearby penetrations.

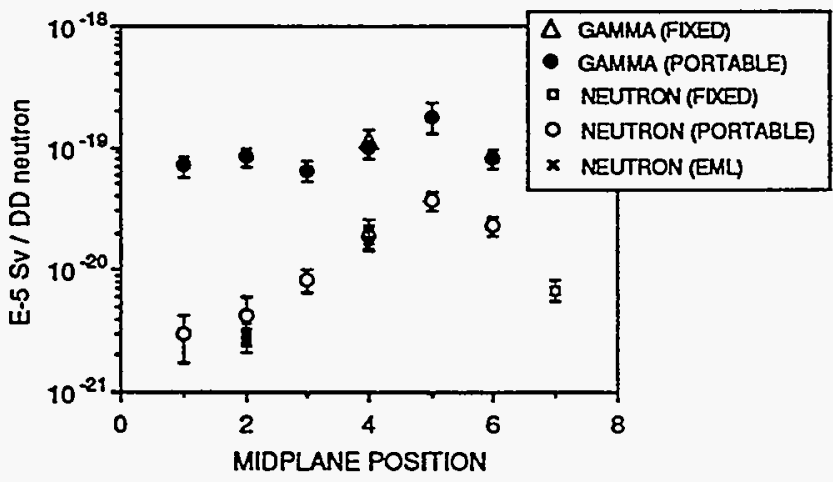

Fig. 7. The measured neutron and gamma dose-equivalent per TFTR D-D neutron along the horizontal midplane at the outside of the Test Cell walls. The measurement locations are given in Fig. 1. Refer to Sec. III for detector type.

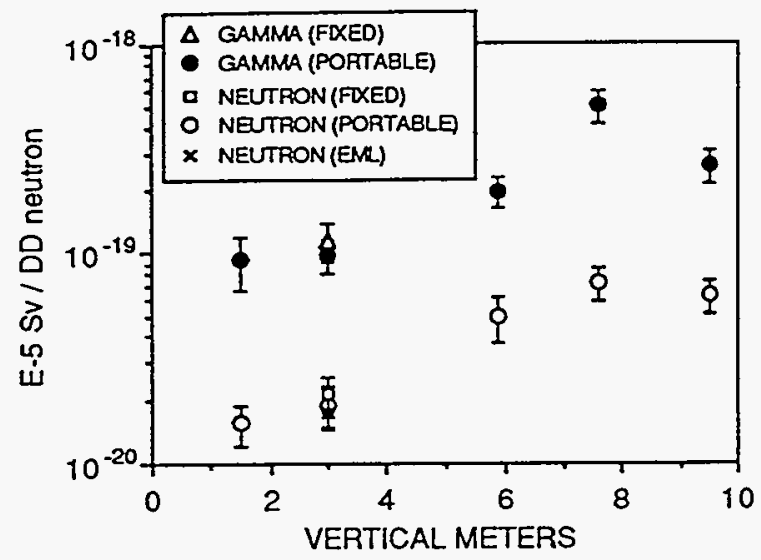

Fig. 8. Results of neutron and gamma dose-equivalent measurements per TFIR D-D neutron along a vertical plane outside Test Cell north wall opposite TFTR. Refer to Sec. III for detector type.

Fig. 8 shows the results of measurements of neutron and gamma dose-equivalents per TFTR D-D neutrons long a vertical plane outside the Test Cell north wall opposite TFTR. The midplane of the vessel is at $3.2 \mathrm{~m}$. The measured neutron and gamma dose-equivalents per TFTR D-D neutron increase with height above ground level as equipment interferences decrease and the top of the auxiliary shielding and the Test Cell ceiling are approached (Fig. 2). At the $9.5 \mathrm{~m}$ position, the line-of-sight from the detectors to the center of the plasma intersected the TFTR upper structure which provided increased attenuation.

The data from areas outside the Test Cell walls appears to correlate with the effects of wall distance from the source and the presence or absence of large shielding structures in the Test Cell. The areas with the highest neutron doseequivalent per source neutron exhibited the highest neutron/gamma dose-equivalent ratio. This is consistent with the gammas being generated after neutron attenuation and moderation occurs.

\section{TFTR TEST CELL WALL NEUTRON ATTENUATION MEASUREMENTS}

Table 1 shows a comparison of Test Cell north wall neutron dose-equivalent attenuation measurements and simulations using TFTR D-D neutrons and an intense ${ }^{252} \mathrm{Cf}$ source. Details of the ${ }^{252} \mathrm{Cf}$ measurement were discussed previously. ${ }^{2}$ These measurements allowed a -determination of the neutron dose-equivalent attenuation. through the $1.5 \mathrm{~m}$ thick concrete wall. It is seen that the measurements and simulation results for the neutron doseequivalent attenuation of the walls are in agreement to within the respective experimental uncertainties. 
TABLE 1. Summary of measured and simulated neutron D-D dose-equivalent attenuations for Test Cell north wall

$$
\text { METHOD }
$$

ATIENUATION

TFTR D-D NEUTRONS

Inside: CR-39/TLD

Outside: Moderated ${ }^{3} \mathrm{He}$ and $\mathrm{BF}_{3}$

TFTR D-D NEUTRONS

Inside: activation foils

Outside: Moderated ${ }^{3} \mathrm{He}$ and $\mathrm{BF}_{3}$

$9.4 \pm 5.0 \times 10^{5}$

SIMULATION for TFTR D-D
NEUTRONS

$8 \times 10^{5}$

${ }^{252}$ Cf NEUTRON SOURCE

Outside: Moderated $\mathrm{BF}_{3}$

$6 \pm 3 \times 10^{5}$

SIMULATION for ${ }^{252} \mathrm{Cf}$

NEUTRONS

$6.5 \times 10^{5}$

\section{OUTWARD ALONG RADIALS FROM TEST CELL WALLS}

Gamma and neutron dose-equivalent measurements were made during high power D-D operations in two radial directions from the TFTR centerline across indoor areas outside the Test Cell walls, and outdoor areas surrounding. the Test Cell. The purpose of these measurements was to provide calibrations for the radiation simulations and to determine the expected dose-equivalents at the nearest property lines during TFTR D-T operations. Fig. 9 shows the results of neutron and gamma dose-equivalent

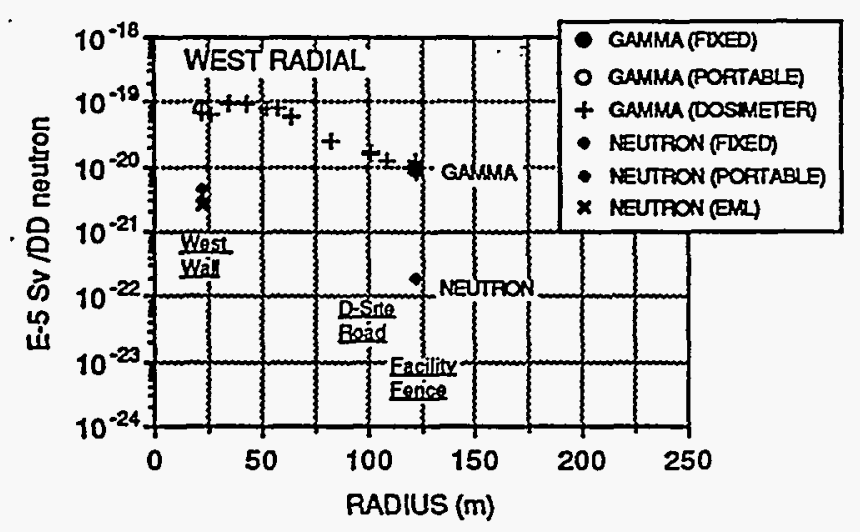

Fig. 9 Measured neutron and gamma dose-equivalents per TFTR D-D neutron along a westward radial from the Test Cell wall to the TFTR site fence at $125 \mathrm{~m}$. Refer to Sec. III for detector type.

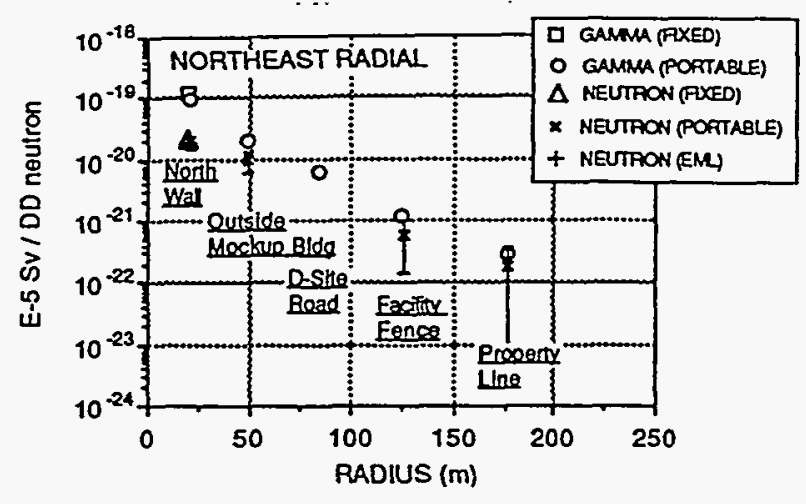

Fig. 10. Measured neutron and gamma dose-equivalents per TFTR D-D neutron along a northeastward radial from the Test Cell wall to the property line at $180 \mathrm{~m}$. Refer to Sec. III for detector type.

measurements from outside of the Test Cell west wall along a westward radius to the $125 \mathrm{~m}$ site boundary fence. There is good agreement between the different neutron and gamma dose-equivalent measurements outside the west wall. Gamma dosimeter measurements made outdoors, along a westward radius found that the gamma doseequivalent peaked at about $40 \mathrm{~m}$ which is about $20 \mathrm{~m}$ beyond the west wall. This may be due in part to the shorter height of the add-on, inner $0.3 \mathrm{~m}$ concrete shield (Fig. 2), which allows more neutrons to escape through the ceiling and upper wall. These neutrons eventually scatter downward, by reflections from the upper regions of the Test Cell and the sky, causing the peak dose-equivalent to occur a distance which is typically displaced from a wall by the wall height. This westward radial has the least obstructed line-of-sight from the Test Cell outer wall to the site boundary fence (Fig. 3). Gamma dosimeter measurements were made out to the site boundary fence. There is close agreement at the $125 \mathrm{~m}$ radius, west, site boundary fence between the gamma dosimeter measurements and the gamma ionization chamber. measurement.

Fig. 10 shows similar measurements from outside the Test Cell north wall along a northeastward radial to the nearest property line at $180 \mathrm{~m}$. The effects of shielding provided by the Mock-up Building, directly north of the Test cell, result in much lower dose-equivalents along the northeastward radius relative to those along the open westward radius noted above. Fig. 10 shows that there is good agreement between the different neutron and gamma dose-equivalent measurements just outside the north wall. Outside the Mock-up Building, the neutron and gamma dose-equivalents fall off smoothly to the $180 \mathrm{~m}$ northeast property line.

\section{E. OUTSIDE RADIATION CONTOUR MEASUREMENTS ON TFTR SITE}

The neutron and gamma dose-equivalents at the four boundary trailers were measured and computer archived for 
each TFTR pulse. Using the portable detectors during high power operations, radiation contour measurements between the boundary trailers were made every $20 \mathrm{~m}$ along the site road around TFTR and along the northward site fence. The results varied smoothly between the values measured at the four boundary trailers which indicated the absence of any significant radiation streaming to within the spatial resolution of the measurements.

\section{COMPARISON OF RADIATION SIMULATION AND D-D DOSE-EQUIVALENT MEASUREMENTS}

An earlier radiation simulation, utilizing a direct: calculation approach was performed to model more accurately the evolving TFTR geometry, to study uncertainties in the initial design, and to study possible options for the experimental program. ${ }^{6-9}$ The simulation was able to resolve some issues by employing a more complex analysis, but also remaining uncertainties were encountered involving radiation response functions, material properties, and changing material distributions. Following this work, high power, high D-D neutron yield experimental conditions became available, and allowed far field measurements described above. The results of the measurements described in this paper were used to provide guidance for additional analysis.

An algorithm was developed to derive the radiation field characteristics in the Test Cell based on the above measurements and comparisons with neutron transport calculations. The field characteristics were derived using data obtained during recent high power D-D operations and used to construct simplified neutron transport models. The models were then used to estimate dose-equivalents expected for D-T pulses both inside and outside the Test Cell. This approach allowed the effects of complex scattering by Test Cell materials to be empirically included in the modeling. The results indicate that the neutron doseequivalent outside the test cell wall effectively depends only on those neutrons impinging on the interior wall surface with energies $\geq 2 \mathrm{MeV} .3,10$ Hence, the neutron doseequivalent outside the wall was found to be sensitive to the local material distribution in the Test Cell in agreement with the measured results discussed above. However, in the case of the gamma dose-equivalent outside the wall, the predominant contribution is due to multiscattered neutrons, and therefore, the details of the local geometry are not as significant as the average material density. A comparison of the total dose-equivalent obtained previously ${ }^{6}$ and the recent results 3,10 shows that in general the new results are lower than the earlier results. This is attributed to scattering and attenuation provided by Test Cell components not included in the earlier simulation. The effect of these Test Cell components was simulated in the transport calculations by including additional steel between the vessel and the walls. A comparison of the calculated and measured dose-equivalents found that the calculated-toexperimental $(C / E)$ values range from 1.05 to 2.75 for neutron dose-equivalents and from 1.47 to 2.73 for gamma dose-equivalents for various locations from outside the Test - Cell walls to the property line. In the northward direction, toward the nearest property line, the neutron doseequivalent $\mathrm{C} / \mathrm{E}$ is 1.05 and the gamma dose-equivalent is 2.73 .

Numerical models able to yield the above consistency with the D-D experimental data were used to calculate the expected D-T dose-equivalents. This simulation found that the $\mathrm{D}-\mathrm{T}$ neutron dose-equivalent is increased from between 11 to 36 outside the Test Cell north wall depending on the local material density, with an average value of about 20 and that the estimated D-T gamma dose equivalent is increased by about 2.5 . Results from this simulation were also used to simulate the prompt dose-equivalent from D-T source neutrons at the TFTR facility boundary and the property line. A formulation was obtained that related the dose-equivalent at the property line to that at the Test Cell wall by a set of transfer coefficients. The coefficients are explicitly given for the present configuration at the west facility fence boundary, the north facility fence boundary, and at the northeast property line. ${ }^{10}$ This analysis indicates that neutrons leaving the roof contribute between $40 \%$ and $20 \%$ of the neutrons at the north and south facility fence boundaries, respectively. These results imply that, if the contribution from the north and west Test Cell walls could be eliminated entirely, the reduction in the total dose equivalent at the north property line would be in the range of about 2 to 3 .

\section{SUPPLEMENTARY SHIELDING}

The $D-D$ radiation measurements discussed above were sufficient to verify the effectiveness of the present shielding for meeting the TFTR design objective of limiting exposures outside the Test Cell walls to $10^{-2} \mathrm{~Sv}$ per calendar year and at the property line to $10^{-4} \mathrm{~Sv}$ per calendar year during planned $\mathrm{D}-\mathrm{T}$ operations yielding $1 \times 10^{21} \mathrm{D}-\mathrm{T}$ neutrons per calendar year. In order to provide extended D-T operation capability involving higher neutron yields, supplementary shielding for the Test Cell, north wall was installed in early 1993 after the completion of the above measurements. This supplemental shielding consists of $0.3 \mathrm{~m}$ thick concrete panels, $2.1 \mathrm{~m}$ wide, and $8.5 \mathrm{~m}$ high, positioned $1.8 \mathrm{~m}$ inward from the north wall. Based on simulations, the attenuation measurements discussed above, and the radiation contour data shown in Fig. 9, it was estimated that this supplementary shielding would reduce the prompt $D-T$ neutron dose-equivalent at the property line by a factor of about 2 to 3 . The limiting factor at the property line being the small but detectable radiation passing over the shielding and reflected by the sky and various structures. Recent preliminary measurements find the resultant D-D neutron dose-equivalent reduced by about a factor of about 3 , consistent with the simulation and measured results in directions with significantly more shielding due to buildings and equipment. This implied that the total property line dose-equivalent for $1 \times 10^{21} \mathrm{D}-\mathrm{T}$ neutrons would be less than $3.6 \times 10^{-5} \mathrm{~Sv}$, and thus would allow a maximum of about $3 \times 10^{21} \mathrm{D}-\mathrm{T}$ neutrons per 
calendar year. Recent D-T measurements have confirmed this prediction based on the D-D results. ${ }^{11}$ Hence, the supplemental shielding significantly extended D-T operational capability and reduced occupational exposures in work areas near the outer north wall.

After the installation of this supplementary shielding, a gamma spectrum (Fig. 11) was collected during D-D operations, after initial trace tritium experiments, outside the Test Cell north wall on the midplane of TFTR using a high purity $\mathrm{Ge}$ detector (41.8\% efficiency relative to 7.6 $\mathrm{cm} \times 7.6 \mathrm{~cm} \mathrm{NaI}$. A computer based spectroscopy system was used and gated to collect signal only during discharges. The background that occurred during these discharges has not been subtracted. Evident are the capture gammas from iron at 7.631 and $7.645 \mathrm{MeV}$ and silicon at $4.934 \mathrm{MeV}$. Also capture gammas from nickel, chromium, and aluminum are suspected. There is no evidence of the hydrogen capture line at $2.223 \mathrm{MeV}$. While the silicon line at $4.934 \mathrm{MeV}$ is clearly present, preliminary analysis of the spectra indicates that the silicon lines at 3.539 and 6.381 are not observable. In addition, there appears to be no structure below $4.9 \mathrm{MeV}$. Moreover, there is no evidence of the gamma lines associated with the interaction of thermal neutrons with germanium, specifically at 0.500 and $0.596 \mathrm{MeV}$ for the $\mathrm{Ge}(\mathrm{n}, \gamma)$ reaction in the detector. This suggests that the thermal neutron fluence was less than $10 \mathrm{n} / \mathrm{cm}^{2}$

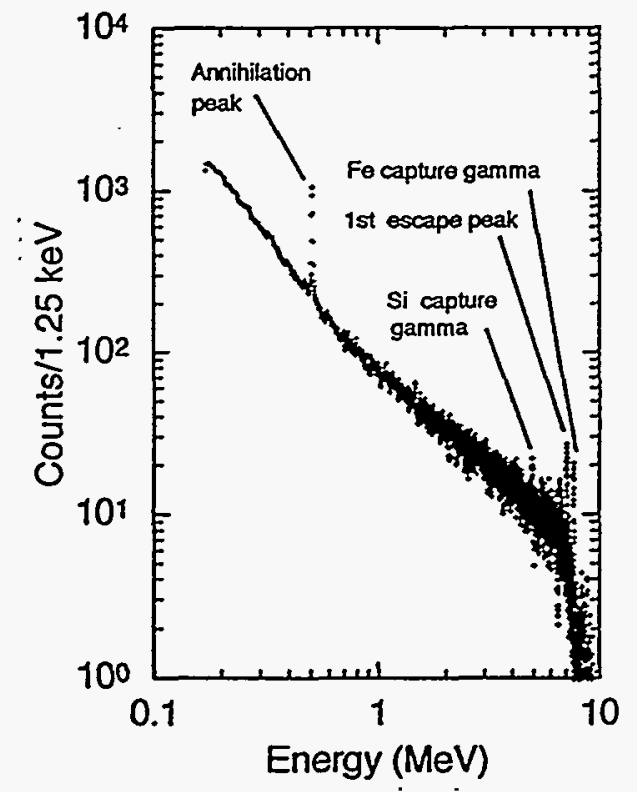

Fig. 11. Composite Ge gamma detector spectrum collected outside the north Test Cell wall on the midplane of TFTR during 48 D-D discharges. Indicated are the full energy absorption peak for thermal capture gammas for iron (7.631 and $7.645 \mathrm{MeV}$ ) and silicon (4.934 MeV). Also indicated are the first escape peaks of iron (7.120 and 7.134 $\mathrm{MeV}$.
The rather strong iron lines cannot be due to the trace amounts of iron in the concrete. There is a possibility that the source may be the reinforcement bars used in the construction of the shield wall. However, given the evidence of nickel and chromium in the spectrum, it is more probable that the source of the iron and the other high energy capture gamma ( $7 \mathrm{MeV}$ and above) are from components within the Test Cell and probably parts of the tokamak itself. The most likely source of the aluminum capture gamma at $7.724 \mathrm{MeV}$ is the shield wall, but its high energy allows for sources within the Test Cell.

The high purity Ge spectrum shown in Fig. 11 appears to have capture gammas from the shield wall, as well as, capture gammas from elements within the Test Cell. The absence of the hydrogen capture line, as well as, the $3.534 \mathrm{MeV}$ line from silicon may be attributable to where these $(n, \gamma)$ reactions occur within the shield wall. The absence of the $6.381 \mathrm{MeV}$ line is probably due to its intensity. It may be that the $4.934 \mathrm{MeV}$ silicon capture gamma is the highest energy gamma that is created in the shield wall that can escape in any detectable quantity.

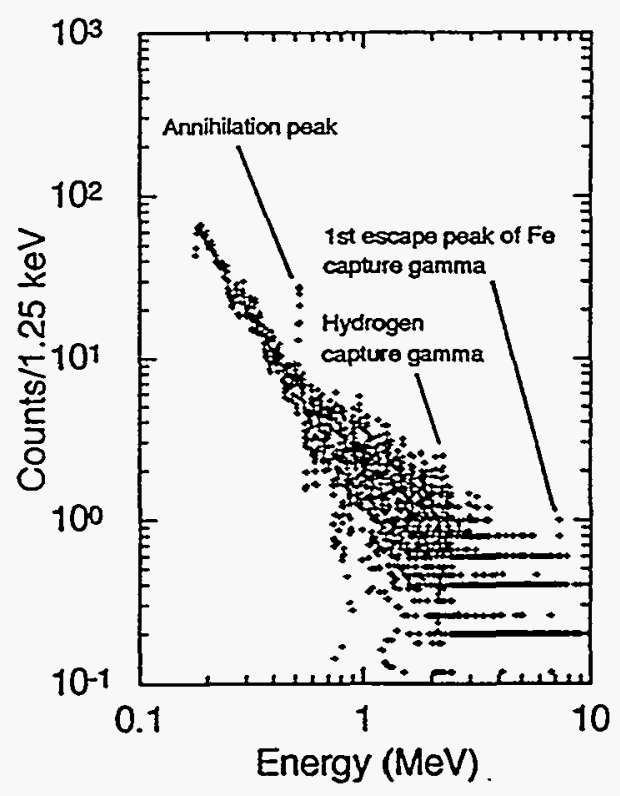

Fig. 12. Composite Ge gamma detector spectrum collected, at the northeastward fence during 32 discharges having a tritium admixture (D-D/D-T neutrons $=1.25$ ). Indicated are the first escape peak of iron (7.120 and 7.134 MeV) and the full energy absorption for hydrogen (2.223 MeV).

Fig. 12 shows a similar gamma spectrum collected during $32 \mathrm{D}-\mathrm{D}$ discharges (1.97 sec duration) inside the northeastward fence monitoring trailer at $125 \mathrm{~m}$ (indicated in Fig. 3) using the same high purity $\mathrm{Ge}$ detector and techniques described above in reference to Fig. 11. These particular D-D discharges occurred after the beginning of tritium operations and contained a tritium admixture yielding a D-D to D-T source neutron ration of about 1.25 . 
Unlike the D-D spectra collected outside the Test Cell wall. (Fig. 11), it was necessary to correct for background during the discharge due to the low signal-to-background ratio. Although the composite spectrum collected at this location suffers from poor statistics, it still exhibits a strong annihilation line. The hydrogen capture is present and the full, single, and double escapes of the iron lines are suspected. Also suspected are the capture gammas of nitrogen. Additional work is in progress to investigate these issues.

\section{SUMMARY AND CONCLUSIONS}

TFTR radiation contour and shielding efficiency measurements were performed during high power D-D operations with high neutron yields. Neutron and gamma dose-equivalent measurements were performed in the tokamak Test Cell, on the midplane at the inner walls, along a vertical from floor to ceiling and along the ceiling over the vessel, at the outer Test Cell wall, in nearby control rooms, work areas, and personnel pathways, outdoors along the site road and fence at $125 \mathrm{~m}$, and out to the nearest property lines at $180 \mathrm{~m}$.

The results were found to be highly dependent on local material density resulting from the complex facility geometry. A recent simulation of the radiation is in agreement with the measured results at fiducial locations. Using the measurement results and the simulated D-T to D$D$ ratios, estimated exposures were obtained for outside the Test Cell walls and at the property lines. The results indicated that the pre 1993 shielding was sufficient to meet the design objectives. The D-D results indicated that the installation of north wall supplementary shielding would significantly extend D-T operational capability by reducing occupational exposures in nearby work areas and allow neutron production yields of about $3 \times 10^{21} \mathrm{D}-\mathrm{T}$ neutrons per calendar year. Recent work has confirmed these estimates.

The work presented in this paper demonstrates the effectiveness of performing extensive D-D radiation contour, shielding efficiency, and spectral measurements for a thorough experimentally-based understanding of the D-D radiation field characteristics of the complex TFTR geometric and material density configuration, and how these measurements and simulations are important for qualifying a reactor's D-T radiation shielding before starting high power operations with tritium fuel.

\section{ACKNOWLEDGMENTS}

We wish to acknowledge helpful technical assistance a from H. Bush., K. Chase, R. Frankenfield, J. Gorman, J. Lehner, H. Murphy, R. Such, C. Szathmary, S. Williams, and helpful discussions with R. Apfel (Yale University), C. Bames (LANL), M. A. Buchner (ORNL), R. Hawryluk, K. Hill, D. Jassby, I. Johnson, E. Perry, and J. D. Strachan. This work was supported by U.S. Department of Energy Contract No. DE-AC02-76-CHO3073.

\section{REFERENCES}

1. R. J. Hawryluk, et al., "Status and Plans for TFTR", Fusion Technol. 21, 1324 (1992).

2. H. W. Kugel, C. W. Barnes, J. Gilbert, et al., "Measurements of TFTR Radiation Shielding During High Power D-D Operations," Fusion Technol. 19 (5), 1989 (1991).

3. L.-P. Ku and S. L. Liew, "A Semi-empirical Algorithm for determining Radiation Field Characteristics in TFTR", Proc. of the 8th Int. Conf. on Radiation Shielding, Arlington, Texas, April 24-28, 1994, p.1062, American Nuclear Society, Inc., La Grange Park, Ill, 60525, 1994.

4. E. F. Plechaty, "Comparison of Evaluated and Experimental Cross Section Data Used in TFTR Shielding," Lawrence Livermore National laboratory, Report UCRL-ID-111075, June 25, 1992, and E. F Plechaty, "TFTR Shielding Review and Calculations on Basic TFTR Materials," Lawrence Livermore National Laboratory, Report UCRL-ID-112155, October 1992.

5. F. Hajnal, et al., "Measurement of the Neutron Radiation Fields at the Princeton Tokamak Fusion Test Reactor (TFTR)", U. S. Department of Energy, Environmental Measurements Laboratory, April 1991.

6. L. P. Ku, J. G. Kolibal, S. L. Liew, "Comparison of 1-, 2-, and 3-Dimensional Modeling of the TFTR for Nuclear Radiation Transport Analysis", Princeton Plasma Physics Laboratory Report No. PPPL-2244, September 1985.

7. J. G. Kolibal, L.-P. Ku, S. L. Liew, "Two Dimensional Prompt Radiation Analyses for the TFTR", Princeton Plasma Physics Laboratory Report No. EAD-R-33 (1985).

8. S. L. Liew, L.-P. Ku, J. G. Kolibal, "ThreeDimensional Monte Carlo Calculations of the Neutron and g-ray Fluences in the TFTR Diagnostic Basement and Comparisons with Measurements", Princeton Plasma Physics Laboratory Report No. PPPL-2275, October 1985.

9. J. G. Kolibal, L.-P. Ku, and S. L. Liew, "TFTR Offsite Dose Levels from Fusion Radiation and Effluent Releases", Fusion Technology, 10, 1234 (1986).

10. L.-P Ku and S. L. Liew, "Calculation of Prompt DoseEquivalent at the TFTR Facility and Site Boundaries", Princeton Plasma Physics Laboratory, ( to be published).

11. H. W. Kugel et al., "Measurements of TFTR D-T Radiation Shielding Efficiency", Proc. of the 3rd Int. Symp. of Fusion Nuclear Technology", June 27-July 1, 1994, Los Angeles, CA. 


\section{EXTERNAL DISTRIBUTION IN ADDITION TO UC-420}

Dr. F. Paoloni, Univ. of Wollongong, AUSTRALIA

Prof. R.C. Cross, Univ. of Sydney, AUSTRALIA

Plasma Research Lab., Australian Nat. Univ., AUSTRALIA

Prof. I.R. Jones, Flinders Univ, AUSTRALIA

Prof. F. Cap, Inst. for Theoretical Physics, AUSTRIA

Prof. M. Heindler, Institut fur Theoretische Physik, AUSTRIA

Prof. M. Goossens, Astronomisch Instituut, BELGIUM

Ecole Royale Militaire, Lab. de Phy. Plasmas, BELGIUM

Commission-European, DG. XII-Fusion Prog., BELGIUM

Prof. R. Bouciqué, Rijksuniversiteit Gent, BELGIUM

Dr. P.H. Sakanaka, Instituto Fisica, BRAZIL

Prof. Dr. I.C. Nascimento, Instituto Fisica, Sao Paulo, BRAZIL Instituto Nacional De Pesquisas Espaciais-INPE, BRAZIL

Documents Office, Atomic Energy of Canada Lid., CANADA

Ms. M. Morin, CCFWTokamak de Varennes, CANADA

Dr. M.P. Bachynski, MPB Technologies, Inc., CANADA

Dr. H.M. Skarsgard, Univ. of Saskatchowan, CANADA

Prof. J. Teichmann, Univ. of Montreal, CANADA

Prof. S.R. Sreenivasan, Univ. of Calgary, CANADA

Prof. R. Marchand, INRS-Energie et Materiaux, CANADA

Dr. R. Bolton, Centre canadien de fusion magnétique, CANADA

Dr. C.R. James, Univ. of Alberta, CANADA

Dr. P. Lukác, Komenského Universzita, CZECHO-SLOVAKIA

The Librarian, Culham Laboratory, ENGLAND

Library, R61, Rutherford Appleton Laboratory. ENGLAND

Mrs. S.A. Hutchinson, JET Library, ENGLAND

Dr. S.C. Sharma, Univ. of South Pacific, FIJI ISLANDS

P. Măhönen, Univ. of Helsinki, FINLAND

Prof. M.N. Bussac, Ecole Polytechnique, FRANCE

C. Mouttet, Lab. de Physique des Milieux lonisés, FRANCE

J. Radet, CEN/CADARACHE - Bat 506, FRANCE

Prof. E. Economou, Univ. of Crete, GREECE

Ms. C. Rinni, Univ. of loannina, GREECE

Preprint Library, Hungarian Academy of Sci., HUNGARY

Dr. B. DasGupta, Saha Inst. of Nuclear Physics, INDIA

Dr. P. Kaw, Inst. for Plasma Research, INDIA

Dr. P. Rosenau, Israel Inst. of Technology, ISRAEL

Librarian, International Center for Theo Physics, ITALY

Miss C. De Palo, Associazione EURATOM-ENEA, ITALY

Dr. G. Grosso, Istituto di Fisica del Plasma, ITALY

Prof. G. Rostangni, Istituto Gas lonizzati Del Cnr, ITALY
Dr. H. Yamato, Toshiba Res \& Devel Center, JAPAN

Prof. I. Kawakami, Hiroshima Univ., JAPAN

Prof. K. Nishikawa, Hiroshima Univ., JAPAN

Librarian, Naka Fusion Research Establishment, JAERI, JAPAN

Director, Japan Atomic Energy Research Inst., JAPAN

Prof. S. Itoh, Kyushu Univ., JAPAN

Research Info. Ctr., National Instit. for Fusion Science, JAPAN

Prof. S. Tanaka, Kyoto Univ., JAPAN

Library, Kyoto Univ., JAPAN

Prof. N. Inous, Univ. of Tokyo, JAPAN

Secretary, Plasma Section, Electrotechnical Lab., JAPAN

Dr. O. Mitarai, Kumamoto Inst. of Technology, JAPAN

Dr. G.S. Lee, Korea Basic Sci. Ctr., KOREA

J. Hyeon-Sook, Korea Atomic Energy Research Inst., KOREA

D.I. Choi, The Korea Adv. Inst. of Sci. \& Tech., KOREA

Prof. B.S. Liley, Univ. of Waikato, NEW ZEALAND

Inst of Physics, Chinese Acad Sci PEOPLE'S REP. OF CHINA

Library, Inst. of Plasma Physics, PEOPLE'S REP. OF CHINA

Tsinghua Univ. Library, PEOPLE'S REPUBLIC OF CHINA

Z. Li, S.W. Inst Physics, PEOPLE'S REPUBLIC OF CHINA

Prof. J.A.C. Cabral, Instituto Superior Tecnico, PORTUGAL

Prof. M.A. Hellberg, Univ. of Natal, S. AFRICA

Prof. D.E. Kim, Pohang Inst. of Sci. \& Tech., SO. KOREA

Prof. C.I.E.M.A.T, Fusion Division Library, SPAIN

Dr. L. Stenflo, Univ. of UMEA, SWEDEN

Library, Royal Inst. of Technology, SWEDEN

Prof. H. Wilhelmson, Chalmers Univ. of Tech., SWEDEN

Centre Phys. Des Plasmas, Ecole Polytech, SWITZERLAND

Bibliotheek, Inst. Voor Plasma-Fysica, THE NETHERLANDS

Asst. Prof. Dr. S. Cakir, Middle East Tech. Univ., TURKEY

Dr. V.A. Glukhikh,Sci. Res. Inst. Electrophys.I Apparatus, USSR

Dr. D.D. Ryutov, Siberian Branch of Academy of Sci., USSR

Dr. G.A. Eliseev, I.V. Kurchatov Inst., USSR

Librarian, The Ukr.SSR Academy of Sciences, USSR

Dr. L.M. Kovrizhnykh, Inst. of General Physics, USSR

Kemforschungsanlage GmbH, Zentralbibliothek, W. GERMANY

Bibliothek, Inst. Für Plasmaforschung, W. GERMANY

Prof. K. Schindler, Ruhr-Universitát Bochum, W. GERMANY

Dr. F. Wagner, (ASDEX), Max-Planck-Institut, W. GERMANY

Librarian, Max-Planck-Institut, W. GERMANY 